Volume 03 Nomor 01, Juni 2021 Page 26-31

Incrementapedia: Jurnal Pendidikan Anak Usia Dini

Program Studi PG-PAUD Fakultas Pedagogi dan Psikologi

Universitas PGRI Adi Buana Surabaya

http://jurnal.unipasby.ac.id/index.php/incrementapedia

e-ISSN: 2686-3146

\title{
PENGARUH PERMAINAN KARTU HURUF TERHADAP KEMAMPUAN MEMBACA ANAK KELOMPOK A DI TK AMANDA CIPTA MENANGGAL SURABAYA
}

\author{
Isabella Hasiana a, \\ ${ }^{a}$ Universitas PGRI Adi Buana Surabaya \\ e-mail korespondensi: Isabella@unipasby.ac.id
}

\begin{abstract}
This research is motivated by the lack of use of letter cards in learning in kindergarten, in this case to develop children's reading skills, it is very necessary to have interesting learning such as letter card games, because by using letter card games develop the ability of the right brain, can recognize letters easily, with letter cards children can learn while playing, so that children are not easily bored and bored, children in kindergarten Amanda are less developed reading skills because of that many children can not read, develop abilities reading children can help children in preparing themselves to enter elementary school, this can make it easier for children to read because children already know the basics.

The purpose of this study was to determine whether there is an effect of the game of letter cards on the reading ability of group A children at TK Amanda Cipta Menanggal Surabaya. The method in this study is a quantitative research method using the type of Pre-Experiential Design in the form of One Group Protest-Postest Design. This quantitative research has 3 stages: pretest, treatment treatment and posttest. Data collection used is observation and documentation.

The results of the study were that there was no effect of letter card games on the reading ability of group A children in Amanda Cipta Menanggal Kindergarten, this was evidenced from the pre-test and post-test data obtained using SPSS v.20 which showed that the sig value obtained was 0,21<0.05, then Ho is automatically accepted Ha is rejected.
\end{abstract}

Keywords: Letter card games, reading ability, early childhood.

\section{PENDAHULUAN}

Pendidikan anak usia dini adalah pendidikan yang diberikan bagi anak usia dini sejak usia 0-6 tahun, dilakukan dengan memberi rangsangan untuk membantu pertumbuhan dan perkembangan jasmani dan rohani agar anak memiliki kesiapan dalam memasuki pendidikan lanjut. Oleh karena itu pelaksanaan pendidikan perlu mendapatkan perhatian agar dapat berjalan optimal (Masganti, 2017:5).
Sementara itu pendidikan anak usia dini sebagai fase pertama sistem pendidikan seumur hidup adalah harus memuat pengembanganketerampilanmendayagunakan informasi dan simbol-simbol, meningkatkan apresiasi bermacam-macam model ekspresi diri, memelihara keinginan dan kemampuan berfikir, menanamkan keyakinan setiap anak tentang proses pendidikan selanjutnya. 
Pendidikan Anak Usia Dini merupakan jenjang pendidikan sebelum jenjang pendidikan dasar sebagai suatu upaya pembinaan yang ditujukan bagi anak sejak lahir sampai dengan usia enam tahun. Dilakukan melalui pemberian rangsangan pendidikan untuk membantu pertumbuhan dan perkembangan jasmani serta rohani agar anak memiliki kesiapan dalam memasuki pendidikan lebih lanjut (Permendikbud No. 146 tahun 2014).

Menurut Undang-Undang Sisdiknas No. 20 tahun 2003 Pasal 1 ayat 14 pendidikan anak usia dini adalah suatu upaya pembinaan yang ditunjukkan kepada anak sejak lahir sampai dengan usia enam tahun yang dilakukan melalui pemberian rangsangan pendidikan untuk membantu pertumbuhan dan perkembangan jasmani dan rohani agar anak memiliki kesiapan dalam memasuki pendidikan lebih lanjut.

Masa perkembangan anak usia dini merupakan masa awal yang paling peka dimana anak berkembang melakukan kegiatan secara spontan dan bebas mengeksplorasi segala sesuatu di sekitarnya (Ali, 2016:7). Anak perlu mendapatkan stimulasi yang tepat agar seluruh aspek perkembangannya dapat berkembang optimal baik aspek kognitif, bahasa, fisik motorik, moral agama, aspek sosial emosional dan seni. Oleh sebab itu aspek perkembangan tersebut tidak dapat dipisahkan satu dengan yang lainnya.

Bahasa (Language) mencakup setiap saran komunikasi dengan menyimbolkan pikiran dan perasaan untuk menyampaikan makna kepada orang lain, termasuk didalamnya seperti : kemampuannya untuk belajar, membantu perasaan harga diri, dan akhirnya meningkatkan kemampuan untuk hidup bersama orang lain (Mulyani, 2016:13).

Aspek bahasa berkembang dimulai dengan peniruan bunyi dan meraban. Perkembangan selanjutnya berhubungan erat dengan perkembangan kemampuan intelektual dan sosial. Bahasa merupakan alat untuk berpikir. Berpikir merupakan suatu proses memahami dan melihat hubungan. Proses ini tidak mungkin dapat berlangsung dengan baik tanpa alat bantu, yaitu bahasa. Bahasa juga merupakan alat komunikasi dengan orang lain dan kemudian berlangsung dalam suatu interaksi sosial. Kemampuan berbahasa juga akan terus berkembang sejalan dengan waktu dan intensitas anak pada teman sebayanya (Susanto, 2011:73).

Proses kegiatan membaca di mulai dari penguasaan kode-kode bahasa, yang diikuti oleh penguasaan kosakata atau perbendaharaan kata, kemudian pemahaman kalimat, paragraf dan sampai pada akhirnya pemahaman teks/wacana (Susanto, 2011:86).

Bahasa adalah suatu sistem yang membantu manusia untuk berkomunikasi atau berhubungan dengan orang lain. Bahasa juga kemampuan manusia yang bersifat bawaan. Bahasa berada di dalam otak manusia dan akan tetap ada walaupun diekspresikan atau tidak. Walaupun kapasitas manusia untuk (memiliki) bahasa bersifat genetik/bawaan, tetapi aspek-aspek bahasa seperti kosakata dan tata bahasa dipelajari. Penguasaan bahasa sebagai alat komunikasi harus melalui tahap perkembangan (Hildayani, 2014: 17). 
tulisan, bicara, bahasa simbol, ekspresi muka, isyarat, pantomim dan seni (Dahlia, 2018:67).

Adapun menurut Havighurst (dalam Susanto, 2017:158) Perkembangan bahasa sangat di pengaruhi oleh hubungan anak yang dilandasi oleh dasar kultural. Hubungan anak yang didasari dari kebudayaan asal. Misal anak lahir dari daerah medan. Orang medan berbicara cepat dan pakai intonasi tinggi, jika dari kecil sudah berada di lingkungan seperti itu lambat laun anak itu pasti mengikuti dengan bahasa dari daerah asalnya. Perkembangan bahasa anak itupun juga mengikuti budaya adanya anak tersebut yaitu berbicara cepat dan dengan nada tinggi. Sama saja jika anak tinggal di daerah solo, yang mayoritas menggunakan Bahasa Jawa maka anak pasti akan mengikuti.

Dari uraian diatas dapat diketahui bahwa pengembangan bahasa yang dilakukan oleh guru harus sesuai dengan tahap perkembangan anak dan menciptakan suasana yang menyenangkan bagi anak.

Proses kegiatan membaca di mulai dari penguasaan kode-kode bahasa, yang diikuti oleh penguasaan kosakata atau perbendaharaan kata, kemudian pemahaman kalimat, paragraf dan sampai pada akhirnya pemahaman teks/wacana (Susanto, 2011:86).

Permainan kartu huruf ini sudah banyak dikembangkan di jepang shicida spesialis perkembangan anak balita, dalam bukunya Right Brain Education menjelaskan hasil studinya, bisa dilihat bagaimana anak-anak SD mampu membaca buku I jilid dalam waktu 3-5 menit

guna memperoleh informasi yang terdapat di dalamnya

Dengan kata lain membaca adalah suatu kegiatan menerjemahkan simbol-simbol kedalam bunyi-bunyi dan memahami maknanya (Christina, 2019:2.1). Adapun pengertian membaca merupakan suatu proses informasi dari teks dan pengetahuan yang dimiliki oleh pembaca mempunyai peranan yang utama dalam berbentuk makna, kemampuan membaca termasuk kegiatan yang kompleks dan melibatkan berbagai keterampilan (Suryana, 2016:127).

Berdasarkan observasi awal di TK Amanda Kelompok A bahwa dari 23 siswa, penulis menemukan permasalahan dalam membaca yaitu 19 siswa belum bisa membaca. Hal ini dikarenakan pembelajaran yang diberikan hanya terbatas pada pengerjaan di Lembar Kerja Siswa (LKS).Oleh karena itu diperlukan cara yang efektif dan menyenangkan agar anak tertarik untuk belajar membaca. Salah satunya dengan menggunakan media kartu huruf.

Kartu huruf adalah penggunaan sejumlah kartu sebagai alat bantu untuk belajar membaca dengan cara melihat dan mengingat bentuk huruf dan gambar yang disertai tulisan dari makna gambar pada kartu (Pangastuti, 2017:55)..Sedangkan Permainan kartu huruf merupakan salah satu metode bermain yang efektif untuk mengembangkan kemampuan mengenal huruf karena anak pada usia 5 sampai 6 tahun masih pada tahap pra operasional yaitu anak belajar melalui benda konkret (Vortuna, dkk 2018:4). 
(Warsiti, 2012:2). Adapun pengertian kartu huruf atau yang disebut dengan kartu abjad meruakan salah satu bentuk dari flash card yaitu kartu kecil yang berisi gambar, huruf, teks atau tanda simbol yang mengingatkan atau menentukan anak kepada sesuatu yang berhubungan dengan simbol-simbol tersebut. Namun demikian kartu huruf yang dimaksud di sini berupa potongan kertas $4 \times 6 \mathrm{~cm}$ yang di dalamnya terdapat tulisan huruf abjad a-z (masing-masing kartu hanya memuat 1 huruf) (Prabawati, 2014:38).

\section{METODE PENELITIAN}

Penelitian ini menggunakan desain PreEksperimental Design dengan bentuk One Grup Pretest-Postest. Dengan tujuan untuk membandingkan antara keadaan sebelum dan sesudah diberikan perlakuan. Besar pengaruh perlakuan dapat diketahui secara akurat dengan membandingkan antara hasil pre-test dengan pos-test.Sampel yang diteliti pada penelitian ini adalah seluruh anak kelompok A sebanyak 23 anak.

$$
\text { Pengumpulan data menggunakan }
$$
instrumen lembar observasi yang digunakan untuk mengamati unjuk kerja anak baik pada saat pre-test maupun post-test. Observasi dilakukan berdasarkan 4 (empat) indikator yang sudah ditetapkan. Keempat indikator tersebut adalah: a) Mengenal simbol-simbol; b) Mengenal suara suara hewan/benda yang ada disekitar; c) Membuat coretan yang bermakna; d) Meniru (menuliskan dan mengucapkan) huruf A-Z. Sedangkan untuk menganalisis data dan menguji hipotesis digunakan uji statistik sesuai dengan rancangan penelitian.

Teknik analisis data yang diterapkan adalah uji t.

\section{HASIL PENELITIAN}

Hasil hitungan dengan bantun SPSS v.20 sebagai berikut:

Tabel 1. Paired Samples Correlations

\begin{tabular}{lccc} 
& $\mathrm{N}$ & Correlation & \multicolumn{1}{l}{ Sig } \\
\cline { 2 - 4 } Pair & & & \\
Pretest\&Posttest & 23 &, 267 &, 218 \\
& & & \\
\hline
\end{tabular}

Dari perhitungan yang telah dilakukan, maka didapatkan $0,218<0,05$ berarti tidak ada pengaruh antara kegiatan permainan kartu huruf dengan kemampuan membaca Pada Kelompok A di TK Amanda Cipta Menanggal Surabaya.

\section{PEMBAHASAN}

Kegiatan pembelajaran yang dilakukan di TK tersebut selama ini berpusat pada guru. Oleh sebab itu peneliti melakukan penelitian untuk meningkatkan kemampuan membaca siswa dengan menggunakan kartu huruf. Alasan dipilihnya kegiatan kartu huruf karena kegiatan kartu huruf merupakan kegiatan yang dimana anak-anak dapat membaca satu suku kata. Selain itu, kegiatan kartu huruf juga merupakan kegiatan menarik bagi anak karena berkaitan dengan huruf dimana anak dapat menyusun huruf sesuai dengan contoh yang diberikan oleh guru. Namun kenyataannya, anak pada kelompok A TK Amanda lupa apa yang dijelaskan oleh peneliti dan contoh yang diberikan sehingga pembelajaran kartu huruf tidak berpengaruh terhadap kemampuan membaca anak. 
Berdasarkan hasil pengamatan membaca, sebelum tindakan menunjukan bahwa membaca anak kelompok A TK Amanda Cipta Menanggal II Surabaya belum berkembang dengan baik. Setelah anak kelompok A TK Amanda mendapatkan tindakan melalui kegiatan kartu huruf ini menunjukkan tidak adanya peningkatan membaca pada anak. Kemampuan anak dalam membaca juga di pengaruhi karena anak sering lupa apa yang telah dijelaskan oleh peneliti dan disekolah tersebut masih menggunakan pembelajaran Lembar Kerja Siswa (LKS) sehingga sebagian anak belum mampu membaca. Seperti pendapat (Olivia, 2008:63).

Pada penelitian ini permainan kartu huruf tidak berpengaruh kemampuan membaca anak, hal ini dikarenakan anak lupa apa yang dijelaskan oleh peneliti dan disekolah tersebut menggunakan metode pembelajaran klasikal dengan menggunakan LKS, sehingga anak kurang memahami dan terbiasa ketika belajar membaca menggunakan kartu huruf. Kendala auditorial pada anak, anak sering lupa apa yang dijelaskan guru, sering lupa membuat tugas yang diinstruksikan guru secara lisan, anak kerap keliru mengerjakan seperti yang diperintahkan guru, dan kesulitan mengekspresikan apa yang dipikirkan.

Pembelajaran berpusat pada guru kurang memberikan peluang dan waktu yang cukup kepada anak untuk merefleksi materi-materi yang dipesentasikan, menerapkan dalam situasi kehidupan nyata. Dengan demikian jelas bahwa kelemahan pembelajaran berpusat pada guru lebih menekankan pada tujuan pembelajaran berupa penambahan pengetahuan, sehingga belajar dilihat dari segi proses hanya berupa kegiatan “meniru”. (Widaningsih, 2019:38).

Pada saat proses membaca, guru belum menyadari pentingnya memberikan stimulasi secara terus-menerus pada anak dimana hal ini yang menyebabkan anak kurang dalam menerima stimulasi sehingga kematangan proses berpikir anak dalam menerima informasi terutama yang berkaitan dengan membaca. Bagi anak yang belum bisa membaca, pada saat guru meminta anak untuk membaca huruf A-Z namun anak tidak dapat menyebutkan huruf tersebut sampai Z .

\section{SIMPULAN DAN SARAN}

\subsection{Simpulan}

Berdasarkan hasil analisis data, maka penelitian ini disimpulkan bahwa media kartu huruf tidak berpengaruh terhadap kemampuan membaca anak usia 4-5 tahun kelompok A Amanda Cipta Menanggal Surabaya.

\subsection{Saran}

Setelah dilakukan penelitian, di bawah ini beberapa saran yang diharapkan dapat menjadi bahan pertimbangan bagi pihak-pihak terkait khususnya dalam dunia pendidikan anak usia dini.Adapun saran dikemukakan sebagai berikut :

\section{Bagi Guru}

Guru hendaknya meningkatkan kreatifitas dalam pemilihan metode pembelajaran agar siswa tidak bosan. 


\section{Bagi Anak}

Diharapkan hasil penelitian ini dapat mmembantu siswa untuk meningkatkan kemampuan membacanya.

3. Bagi peneliti selanjutnya

Sebagai bahan masukan dan referensi bagi peneliti berikutnya yang melakukan penelitian yang berhubungan dengan penelitian ini.

\section{REFERENSI}

Ali, Noor Rochmad. 2016. Perkembangan dan Permainan Edukatif Anak Usia Dini. Yogyakarta: Editie Pustaka.

Christina. 2019. Mengajar Membaca Itu Mudah. Yogyakarta : CV Alaf Media.

Dahlia. 2018. Psikologi Perkembangan Anak Usia Dini. Yogyakarta : Pustaka Pelajar.

Hildayani, Rini. 2014. Psikologi Perkembangan Anak. Tangerang Selatan : Universitas Terbuka.

Kurnia, Rita. 2019. Bahasa Anak Usia Dini. Yogyakarta : Deepublish.

Madyawati, Lilis. 2017. Strategi Pengembangan Bahasa Pada Anak. jakarta : Kencana.

Masganti. 2017. Psikologi Perkembangan Anak Usia Dini. Jakarta : Kencana.

Mulyani, Novi. 2018. Perkembangan Dasar Anak Usia Dini. Yogyakarta : Gava Media

Olivia, Femi. 2008. Mengoptimalkan Otak Dengan Sistem Biolearning. Jakarta : Elex Media Komputindo.
Susanto, Ahmad. 2011. Perkembangan Anak Usia Dini. Jakarta :Kencana. 2017. PendidikanAnakUsiaDini. Jakarta :Kencana.

Undang-undang Republik Indonesia Nomor 20. 2003.

Warsiti. Peningkatan Kemampuan Membaca Awal Anak Melalui Kartu Huruf Pada Kelompok B [skripsi]. Surakarta.

Widaningsih, Ida. 2019. Strategi dan Inovasi Pembelajaran Bahasa Indonesia Diera Revolusi. Ponorogo : Uwais Inspirasi Indonesia.

Vortuna, Dewi, dkk. 2018. Peningkatan Kemampuan Mengenal Huruf Melalui Permainan Kartu Huruf Pada Kelompok B. 5(2): 4 . 